\title{
EFFECTS OF PH, TEMPERATURE, IONIC STRENGTH AND ORGANIC MATTER ON TRICLOCARBAN SOLUBILITY
}

\author{
Georgeta Ramona IVAN ${ }^{1,2 *}$, Ion ION ${ }^{2 \#}$, Luiza CAPRA ${ }^{1}$, Alina Catrinel ION ${ }^{2}$ \\ ${ }^{1}$ Department of Analysis, Tests and Testing, National Research \& Development Institute for Chemistry and \\ Petrochemistry ICECHIM, 202 Splaiul Independentei Str., 060021 Bucharest, Romania \\ ${ }^{2}$ Department of Analytical Chemistry and Environmental Engineering, Faculty of Applied Chemistry and \\ Materials Science, "Politehnica" University of Bucharest, Polizu Str. 1-6, 011061 Bucharest, Romania
}

Received 03 March 2020; accepted 28 December 2020

\author{
Highlights \\ The TCC solubility is influenced by the variation of temperature, ionic strength and the concentration of the organic \\ matter. \\ The variation of the $\mathrm{pH}$ was notice not to have a major influence on the solubility of TCC. \\ In natural waters the TCC solubility is influenced by the chemical composition of the natural matrix.
}

\begin{abstract}
The solubility of triclocarban in ultrapure water and in several natural aqueous solutions is influenced by several environmental factors. In this study the variation of temperature, $\mathrm{pH}$, ionic strength and concentration of the organic matter over the solubility of triclocarban was analysed. The results show that the solubility of triclocarban increases by increasing the contact time, longer than the time of equilibrium and the temperature. It is less influenced by the variations of $\mathrm{pH}$ and strongly influenced by the variation of ionic strength and by the natural organic matter into the studied aqueous matrices.
\end{abstract}

Keywords: solubility, triclocarban, aqueous solutions, water pollution.

\section{Introduction}

Triclocarban (TCC, 3,4,4'-trichlorocarbanilide, $\mathrm{C}_{13} \mathrm{H}_{9} \mathrm{C}_{13} \mathrm{~N}_{2} \mathrm{O}$ ) is used as an antimicrobial agent in disinfectants, detergents, deodorants and cosmetics (INERIS, 2016; Ding et al., 2015). Mostly, TCC is used in liquid soaps in concentrations up to $1.5 \%$ and in body care products in concentrations up to $0.2 \%$ (European Commission, 2005). TCC is added in cosmetics and in pharmaceutical disinfectants in concentrations of up to a maximum $0.2 \%$ (Council Directive, 1976). Its high consumption has led to its presence in the environment, due to the incomplete removal by wastewater treatment (Vimalkumar et al., 2019).

Available data indicate that triclocarban is mainly found in natural systems, in the aquatic environment (Aris et al., 2020; Wanga et al., 2020; Kennedy et al., 2015) and especially in sediments due to its hydrophobic character (Halden \& Paull, 2005). Its use in house and personal cleaning products might be a source of environmental contamination by discharging waste water from wastewater treatment plants. The concentration of TCC in wastewater is $0.4-50 \mu \mathrm{g} / \mathrm{L}$, as indicated by (Halden \& Paull, 2004; Snyder et al., 2010).

TCC has been detected in many surface waters or even in drinking water, mainly in China and the USA, at concentrations in the range of $0.05-6.750 \mathrm{ng} / \mathrm{L}$ ( $\mathrm{Lv}$ et al., 2014). The maximum concentrations detected in other countries, such as India and South Africa, were 1119 and 360 ng/L, respectively (Lehutso et al., 2017; Vimalkumar et al., 2018). Data concerning its concentrations in surface waters in Europe are scarce, probably due to its limited industrial use.

Some studies take into account the changes in its concentration in natural waters, due to the release of triclocarban from aqueous sediments (Zhao et al., 2013; Miller et al., 2008; Venkatesan et al., 2012; Cantwell et al., 2010). The sediments can play a double role: as natural sorbents

\footnotetext{
${ }^{\star}$ Corresponding author. E-mail: georgeta.ratea@gmail.com

\#Corresponding author. E-mail: i_ion2000@yahoo.com

Copyright $\odot 2021$ The Author(s). Published by Vilnius Gediminas Technical University
}

This is an Open Access article distributed under the terms of the Creative Commons Attribution License (http://creativecommons.org/licenses/by/4.0/), which permits unrestricted use, distribution, and reproduction in any medium, provided the original author and source are credited. 
for the adsorption of TCC and as potential sources of contamination through TCC desorption.

This organic contaminant has recently been considered as a new type of endocrine disruptor that can alter gene transcription (Hynther et al., 2011) and which bioaccumulates in algae (Schebb et al., 2011), as a poorly watersoluble compound, resistant to biodegradation due to its aromatic nature.

Studies over the solubility of TCC in different organic solvents are presented in the literature (Diana et al., 2009; Junhyuk et al., 2013; Delgado et al., 2012, 2018). Its solubility has been studied in alcohols $(\mathrm{ROH})$, isopropyl myristate (IPM), chloroform (CLF) and heptane (HPT), at various temperatures, being observed that it decreases in the following order: ROH $>$ IPM $>$ CLF $>$ HPT (Sangster, 1997; Mora \& Martínez, 2007). The best value of the solubility of TCC was obtained in $\mathrm{ROH}$ at $308.15 \mathrm{~K}$ $\left(7.34 \times 10^{-2} \mathrm{~mol} / \mathrm{L}\right)$, while the value was smaller in HPT at $308.15 \mathrm{~K}\left(2.39 \times 10^{-4} \mathrm{~mol} / \mathrm{L}\right)$. Solubility of TCC in pure alcohols (ethanol, 1-propanol, 1-butanol, 1-pentanol, 1-hexanol and 1-heptanol) in the range of temperatures $278.15-318.15 \mathrm{~K}$, increases by rising temperature and by the length of the alkyl chain of the selected alcohol. The highest value was reported in 1-heptanol at $308.15 \mathrm{~K}$ (0.0089 molal fraction), while the lowest was obtained in ethanol at $308.15 \mathrm{~K}$ (0.0025 molal fraction).

In the literature, the studies over TCC solubility report different values in aqueous media, between 0.11 and $1.6 \mathrm{mg} / \mathrm{L}$ and different values of its $\log$ Kow between 3.5-4.2 (Snyder \& O'Connor, 2013), according to Table 1.

Table 1. Data on TCC solubility from the literature

\begin{tabular}{|c|c|l|l|}
\hline $\begin{array}{c}\text { Solubility of } \\
\text { TCC, } \mathrm{mg} / \mathrm{L}\end{array}$ & $\begin{array}{c}\text { Log } \\
\text { Kow }\end{array}$ & \multicolumn{1}{|c|}{ Observations } & \multicolumn{1}{|c|}{ Ref. } \\
\hline 0.11 & - & $\begin{array}{l}\text { early } \\
\text { measurements }\end{array}$ & Roman et al. (1957) \\
\hline $0.11-1.1$ & - & $\begin{array}{l}\text { OECD, Paris, } \\
\text { 1981, Test } \\
\text { Guideline 105, } \\
\text { Decision of the } \\
\text { Council C (81) 30 }\end{array}$ & $\begin{array}{l}\text { TCC Consortium } \\
\text { (2002), } \\
\text { Commission } \\
\text { Directive (1992) }\end{array}$ \\
\hline $0.65-1.55$ & $4.2-$ & $\begin{array}{l}\text { QSAR (Quanti- } \\
\text { tative Structure- } \\
\text { Activity Relation- } \\
\text { ships) analysis }\end{array}$ & $\begin{array}{l}\text { Halden and Paull } \\
\text { (2005), Sapkota } \\
\text { et al. (2007), Ying } \\
\text { et al. (2007) }\end{array}$ \\
\hline 0.045 & 3.5 & $\begin{array}{l}\text { EPA Product } \\
\text { Characteristics } \\
\text { Test Guideline } \\
\text { OPPTS 830.7840; } \\
\text { Water Solubility - } \\
\text { column elution } \\
\text { method (USEPA, } \\
\text { 1996a) }\end{array}$ & Snyder et al. (2010) \\
\hline
\end{tabular}

In this study the effects of temperature, $\mathrm{pH}$, ionic strength and the concentration of organic matter on the solubility of TCC in aqueous solutions were analysed. The influence of contact time on the solubility of TCC was firstly determined in ultrapure water to establish the equilibrium time needed till the concentration of TCC remains constant in solution. In order to study the solubility of TCC in natural conditions, experiments were carried out in five natural waters with known chemical compositions.

This research supplies data still not reported in the literature on the solubility of TCC in aqueous matrices with different chemical compositions. In order to understand the behavior of TCC in natural aqueous environments future research studies to remove TCC from natural waters will be conducted.

\section{Materials and methods}

\subsection{Materials}

In this study there were used: triclocarban (TCC), (99\% minimum purity), Fluka/Sigma-Aldrich Chemical, Germany; humic acid, Sigma-Aldrich; $0.1 \mathrm{~mol} / \mathrm{L}$ sodium chloride $(0.1 \mathrm{~N})$, Scharlau; acetonitrile HPLC grade, Merck; PTFE diaphragm syringe filters, 0.22 micrometres pore dimension; ultrapure water produced by the Milli-Q Integral system (Merck); samples of surface natural water, natural mineral water and drinking water.

\subsection{Apparatus}

- HPLC Agilent 1100 Series equipped with a binary pump, a degasser, an autosampler, a spectrophotometric detector in UV-Vis and Agilent Chemstation software for data acquisition and analysis.

- Binder incubator in the temperature range $\left(-10 \div 100{ }^{\circ} \mathrm{C}\right)$.

- Shaker with horizontal movement Laboshake, Gerhardt.

\subsection{Description of the experiments}

The experiments over TCC solubility were performed at three temperatures, in aqueous solutions, the following influences being studied: temperature $\left(5,25\right.$ and $\left.40^{\circ} \mathrm{C}\right)$; contact time, at $25^{\circ} \mathrm{C} ; \mathrm{pH}$ at $25^{\circ} \mathrm{C}$; ionic strength (solution $0.01,0.05$ and $0.1 \mathrm{~mol} / \mathrm{L} \mathrm{NaCl}$ ); concentration of natural organic matter NOM $(10,50$ and $100 \mathrm{mg} / \mathrm{L}$ humic acid) and chemical composition of the natural water.

\subsection{HPLC analytical conditions}

HPLC determinations were performed using an Agilent 1100 Series HPLC chromatograph, equipped with a binary pump, spectrophotometric detector in UV-Vis, degasser, autosampler and Agilent Chemstation software for data acquisition and analysis (Ion et al., 2019a). Chromatographic parameters were: injection volume: $50 \mu \mathrm{L}$; analysis time: $6 \mathrm{~min}$; column temperature: $25^{\circ} \mathrm{C}$; column: C18 (Zorbax Eclipse Plus-Agilent), $3.5 \mu \mathrm{m}, 100 \times 4.6 \mathrm{~mm}$ id; flow rate: $1 \mathrm{ml} / \mathrm{min}$, isocratic conditions $80: 20 \mathrm{~A}: \mathrm{B}$ $(\mathrm{v} / \mathrm{v})$, where $\mathrm{A}$ - acetonitrile and B - HPLC ultrapure 
water. Before each series of chromatographic separations, the analytical column is conditioned for 30 minutes with acetonitrile and equilibrated with acetonitrile: water mixture $(80: 20 \mathrm{v} / \mathrm{v})$. TCC monitoring was performed at $\lambda=$ $265 \mathrm{~nm}$ by using the UV-Vis spectrophotometric detector. The identification is performed by comparing the retention time of the analysed compound with the retention time of the standard solution.

\subsection{Characterization of natural waters used in the experiments}

The natural waters used for this study were characterized, the values of: $\mathrm{pH}$, electrical conductivity (EC), cations concentrations $\left(\mathrm{Na}^{+}, \mathrm{K}^{+}, \mathrm{Ca}^{2+}\right.$ and $\left.\mathrm{Mg}^{2+}\right)$, anions concentrations $\left(\mathrm{Cl}^{-}, \mathrm{NO}_{3}{ }^{-}\right.$and $\left.\mathrm{SO}_{4}{ }^{2-}\right)$ and total hardness, being presented in Table 2. The composition of natural waters has been determined by several techniques, such as: electrochemical, volumetric, gravimetric and inductively coupled plasma optical emission spectrometry (ICP-OES).

Table 2. Physical-chemical characterization of natural waters

\begin{tabular}{|l|c|c|c|c|c|}
\hline Elements & $\begin{array}{c}\text { Mineral } \\
\text { water } \\
(\mathrm{M})\end{array}$ & $\begin{array}{c}\text { Surface } \\
\text { water } \\
(\mathrm{F})\end{array}$ & $\begin{array}{c}\text { Surface } \\
\text { water } \\
(\mathrm{B})\end{array}$ & $\begin{array}{c}\text { Surface } \\
\text { water } \\
(\mathrm{A})\end{array}$ & $\begin{array}{c}\text { Drinking } \\
\text { water } \\
(\mathrm{D})\end{array}$ \\
\hline $\mathrm{pH}$ & 7.5 & 7.7 & 8.1 & 8.3 & 8.0 \\
\hline $\begin{array}{l}\mathrm{EC} \text { at } 25, \\
\mathrm{mS} / \mathrm{cm}\end{array}$ & 2.58 & 1.37 & 0.66 & 0.30 & 0.54 \\
\hline $\mathrm{Na}^{+}, \mathrm{mg} / \mathrm{L}$ & 14.5 & 6.86 & 10.6 & 2.68 & 7.0 \\
\hline $\mathrm{K}^{+}, \mathrm{mg} / \mathrm{L}$ & 4.25 & 3.93 & 8.40 & 1.79 & 2.52 \\
\hline $\mathrm{Ca}^{2+}, \mathrm{mg} / \mathrm{L}$ & 524 & 287 & 109 & 46.1 & 98.0 \\
\hline $\mathrm{Mg}^{2+}, \mathrm{mg} / \mathrm{L}$ & 117 & 83.0 & 14.0 & 11.5 & 4.8 \\
\hline $\mathrm{SO}_{4}{ }^{2-}, \mathrm{mg} / \mathrm{L}$ & 1412 & 22.9 & 61.2 & 6.17 & 23.4 \\
\hline $\mathrm{Cl}^{-}, \mathrm{mg} / \mathrm{L}$ & 17.1 & 7.80 & 26.2 & 1.02 & 19.3 \\
\hline $\mathrm{NO}_{3}{ }^{-}, \mathrm{mg} / \mathrm{L}$ & 3.3 & 0.045 & 28.2 & 3.60 & 25.4 \\
\hline $\mathrm{TH}^{\circ}{ }^{\circ} \mathrm{F}$ & 179 & 101 & 32.5 & 15.1 & 26.2 \\
\hline
\end{tabular}

Note: where the following abbreviations were used: EC - electrical conductivity; $\mathrm{TH}-$ total hardness $\left(1{ }^{\circ} \mathrm{f}=0.2 \mathrm{meq} / \mathrm{l}=\right.$ $0.1 \mathrm{~mol} / \mathrm{l} \mathrm{Ca} \mathrm{si} \mathrm{Mg).}$

\subsection{Preparation of TCC solutions}

Stock standard solutions of $1000 \mathrm{mg} / \mathrm{L}$ and $100 \mathrm{mg} / \mathrm{L} \mathrm{TCC}$ concentrations were prepared, using acetonitrile as solvent. The stock solutions were stored in the refrigerator at $2-6{ }^{\circ} \mathrm{C}$ for one week. The standard working solutions were daily prepared by dilution from the stock solution of $100 \mathrm{mg} / \mathrm{L}$, with HPLC grade acetonitrile (Ion et al., 2019b).

An external standard calibration method was used to quantify the TCC concentration. Two calibration curves were used on the domains: $1 \mu \mathrm{g} / \mathrm{L} \div 100 \mu \mathrm{g} / \mathrm{L}$ and $10 \mu \mathrm{g} / \mathrm{L}$ $\div 400 \mu \mathrm{g} / \mathrm{L}$. The calibration curves were constructed according to the TCC concentration in the working standards.

\subsection{TCC solubility experiments}

Volumes of TCC stock solutions were added in $25 \mathrm{~mL}$ aqueous solution as follows: $25 \mu \mathrm{L}$ stock solution of 100 ppm TCC were added in $25 \mathrm{~mL}$ of each aqueous solution, in $60 \mathrm{~mL}$ brown bottles. The aqueous solutions were placed in incubator at temperatures of $5{ }^{\circ} \mathrm{C}, 25^{\circ} \mathrm{C}$ and $40{ }^{\circ} \mathrm{C}$, on a horizontal motion shaker with a stirring speed of $120 \mathrm{rpm}$, being observed that TCC concentration did not modify after 4 hours. $1 \mathrm{~mL}$ volume of each studied solution was sampled from the working solutions, filtered through $0.22 \mu \mathrm{m}$ PTFE membrane syringe filters and the concentration of TCC was chromatographically analysed.

\subsection{Determination of pseudo-first order rate constants and half-lives}

The dissolution of TCC in aqueous solution seems to be pseudo first-order with respect to the compound of interest.

Pseudo first-order rate constants were determined by the slope of the linear dependence $\ln \left(C_{t} / C_{0}\right)$ vs. time for each set of conditions (temperature, $\mathrm{pH}$, ionic strength, organic matter concentration of studied natural waters) (Eq. (1)) (Loftin et al., 2008).

$$
\ln \left(\frac{C_{t}}{C_{0}}\right)=-k^{\prime} t
$$

where: $C_{0}-$ TCC concentration at $t=0 ; C_{t}-$ TCC concentration at the time $(t) ; k^{\prime}$ - pseudo first-order rate constant ( 1 /time) and $t$ - time

Half-lives $\left(t_{1 / 2}\right)$ represent the amount of time needed by a compound to reach one-half of its initial concentration. The mathematical expression for the half-lives is given by Eq. (2):

$$
t_{1 / 2}=\frac{\ln 2}{k^{\prime}} .
$$

Half-lives were calculated for each rate constant for each set of conditions.

\section{Results and discussions}

\subsection{Influence of the contact time over the TCC concentration in ultrapure water, at $25^{\circ} \mathrm{C}$}

The variation in time of TCC concentration in ultrapure water, at $25{ }^{\circ} \mathrm{C}$ was studied to determine the contact time after the concentration of the solubilized TCC becomes constant. The experiments were carried out at $25{ }^{\circ} \mathrm{C}$ with continuous stirring (120 rpm) for 6 hours, in an incubator. The obtained results are presented in Figure 1.

From the measured data it is observed that the concentration of TCC increases over time, remaining constant after 3 hours of shaking. The TCC spectrum is characterized by two absorption peaks in the UV region at 205 and $265 \mathrm{~nm}$. Given the low absorptive behaviour in visible light, the period of three hours accounts only for the 


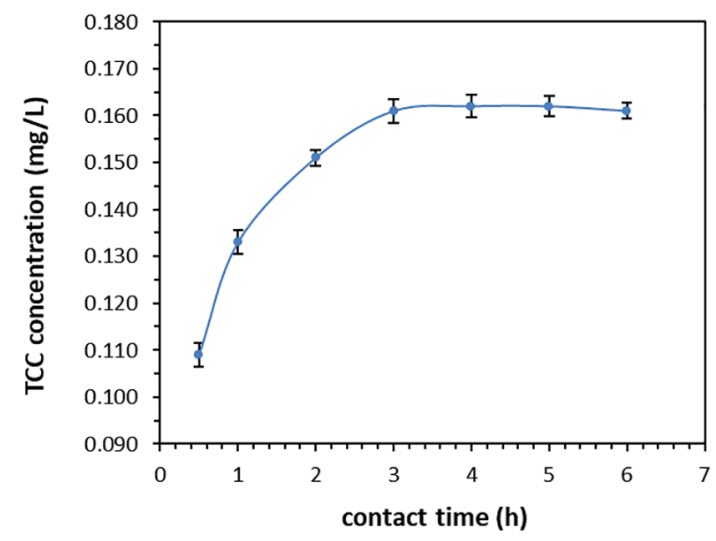

Figure 1. Variation of TCC concentration in time, in ultrapure water, at $25^{\circ} \mathrm{C}$

solubility variation in time and not for other degradation processes of TCC, such as hydrolysis or photodegradation, which are reduced in these experimental conditions.

\subsection{Effect of temperature on TCC concentration in aqueous solutions}

The effect of temperature on the solubility of TCC was performed in ultrapure water at temperatures 5, 25 and $40{ }^{\circ} \mathrm{C}$ using an incubator equipped with a stirrer. The three chosen temperatures are specific to the cold, medium and hot seasons. The experiments were performed in triplicate and the averaged obtained results are presented in Table 3.

Table 3. Effect of the temperature variation over the values of kinetic constants of the pseudo-first order model

\begin{tabular}{|c|c|c|c|c|}
\hline $\begin{array}{c}\text { Tem- } \\
\text { pera- } \\
\text { ture, }{ }^{\circ} \mathrm{C}\end{array}$ & $\begin{array}{c}\text { TCC } \\
\text { concentration, } \\
\mathrm{mg} / \mathrm{L}\end{array}$ & $\begin{array}{c}\text { Pseudo first- } \\
\text { order rate } \\
\text { constant, } k^{\prime}\end{array}$ & $\begin{array}{c}\text { Half-lives, } \\
t_{1 / 2}, \mathrm{~h}\end{array}$ & $R^{2}$ \\
\hline 5 & $0.104( \pm 0.002)$ & 0.209 & 3.32 & 0.9451 \\
\hline 25 & $0.162( \pm 0.001)$ & 0.202 & 3.43 & 0.9398 \\
\hline 40 & $0.172( \pm 0.002)$ & 0.192 & 3.60 & 0.9357 \\
\hline
\end{tabular}

The obtained results indicate an increase of TCC solubility by increasing temperature, based on the variation of the Gibbs free energy: $\Delta \mathrm{G}=-\mathrm{RT} \ln \mathrm{K}$, where $\Delta \mathrm{G}$ represents the Gibbs free energy from the transfer reaction, $\mathrm{R}$ is the ideal gas constant $(\mathrm{J} / \mathrm{mol} \cdot \mathrm{K})$ and $\mathrm{T}$ is the temperature $(\mathrm{K})$. It is observed from the formula that by increasing temperature, the value of partition constant $\mathrm{K}$ is reduced and $\mathrm{S}$ increases, based on the correlation between solubility S and $\mathrm{K}: \operatorname{logS}(\mathrm{mol} / \mathrm{L})=$ 0.796-0.854 logKow (Borrirukwisitsak et al., 2012). The values of Kow show the partition of the organic compounds dissolved between an aqueous and an organic medium, being correlated with the solubility of the compound in aqueous and organic media.

\subsection{Effect of $\mathrm{pH}$ on TCC concentration in aqueous solutions}

$\mathrm{pH}$ is an important factor which influences the TCC solubility. The $\mathrm{pH}$ of ultrapure water was modified by adding $0.1 \mathrm{M} \mathrm{HCl}$ solution and $0.1 \mathrm{M} \mathrm{NaOH}$ solution. The effect of $\mathrm{pH}$ over the TCC concentration was studied at different pH values: 5, 7 and 9 in three replicates. The obtained results are presented in Table 4.

Table 4. Effect of the $\mathrm{pH}$ variation over the values of kinetic constants of the pseudo-first order model, at $25^{\circ} \mathrm{C}$

\begin{tabular}{|c|c|c|c|c|}
\hline $\mathrm{pH}$ & $\begin{array}{c}\text { TCC concent- } \\
\text { ration, mg/L }\end{array}$ & $\begin{array}{c}\text { Pseudo first- } \\
\text { order rate } \\
\text { constant, } k^{\prime}\end{array}$ & $\begin{array}{c}\text { Half-lives, } \\
t_{1 / 2}, \mathrm{~h}\end{array}$ & $R^{2}$ \\
\hline 5 & $0.127( \pm 0.004)$ & 0.197 & 3.52 & 0.9417 \\
\hline 7 & $0.102( \pm 0.004)$ & 0.221 & 3.14 & 0.9369 \\
\hline 9 & $0.121( \pm 0.002)$ & 0.198 & 3.50 & 0.9328 \\
\hline
\end{tabular}

From the presented data it is observed that the concentration of TCC varies between 0.10 and $0.13 \mathrm{mg} / \mathrm{L}$, in the $\mathrm{pH}$ range between 5 and 9. TCC is a trichlorocarbanilide with a $\mathrm{pKa}$ value of 12.9 , its dissociation process in aqueous solutions occurring at $\mathrm{pH}$ values higher than 13 . Only above this $\mathrm{pH}$ value, the TCC ionization form predominates and subsequently the solubility will be influenced by $\mathrm{pH}$ value. In acidic solutions, the reactivity of the amino functionalization decreases due to the protonation.

\subsection{Effect of ionic strength on TCC concentration in aqueous solutions}

The study of the effect of ionic strength on the solubility of TCC was performed in $\mathrm{NaCl}$ solutions of concentrations in the range $0.01-0.1 \mathrm{~mol} / \mathrm{L}$ at $25{ }^{\circ} \mathrm{C}$. The experiments were performed in triplicate, and the average results obtained is presented in Table 5 .

Table 5. Effect of the ionic strength variation over the values of the kinetic constants of the pseudo-first order model, at $25^{\circ} \mathrm{C}$

\begin{tabular}{|c|c|c|c|c|}
\hline $\begin{array}{c}\mathrm{NaCl} \\
\text { concen- } \\
\text { tration } \\
\text { solution, } \\
\mathrm{mol} / \mathrm{L}\end{array}$ & $\begin{array}{c}\text { TCC } \\
\text { concentration, } \\
\mathrm{mg} / \mathrm{L}\end{array}$ & $\begin{array}{c}\text { Pseudo } \\
\text { first- } \\
\text { order rate } \\
\text { constant, } \\
k^{\prime}\end{array}$ & $\begin{array}{c}\text { Half-lives, } \\
t_{1 / 2}, \mathrm{~h}\end{array}$ & $R^{2}$ \\
\hline 0.01 & $0.0860( \pm 0.0031)$ & 0.526 & 1.32 & 0.9361 \\
\hline 0.05 & $0.0700( \pm 0.0021)$ & 0.563 & 1.23 & 0.9224 \\
\hline 0.1 & $0.0500( \pm 0.0015)$ & 0.594 & 1.17 & 0.9228 \\
\hline
\end{tabular}

From the obtained data, it is observed the decrease of the TCC concentration by increasing $\mathrm{NaCl}$ concentration between 0.01 and $0.1 \mathrm{M}$, in order to adjust the ionic strength. The obtained data confirm the salt effect already presented in the literature, based on the influence of the salt concentration on the solubility of organic compounds in solution. More hydrophobic the organic compound, more its solubility in the aqueous environment will be 
reduced (salting-out effect). In the presence of higher concentration of the salt, TCC will predominate into the organic phase of a biphasic system, aqueous - organic.

\subsection{Effect of organic matter concentration on the variation of TCC concentration in aqueous solutions}

The study of the effect of organic matter on the TCC concentration in aqueous solutions was carried out in humic acid $(\mathrm{AH})$ solutions in concentrations ranging from 10 to $100 \mathrm{mg} / \mathrm{L}$ at $25^{\circ} \mathrm{C}$. The experiments were performed in triplicate and the averaged results obtained are presented in Table 6.

Table 6. Effect of humic acid (HA) concentration over the values of the kinetic constants of the pseudo-first order model, at $25^{\circ} \mathrm{C}$

\begin{tabular}{|c|c|c|c|c|}
\hline $\begin{array}{c}\text { HA concen- } \\
\text { tration } \\
\text { solution, } \\
\mathrm{mg} / \mathrm{L}\end{array}$ & $\begin{array}{c}\text { TCC con- } \\
\text { centration, } \\
\mathrm{mg} / \mathrm{L}\end{array}$ & $\begin{array}{c}\text { Pseudo first- } \\
\text { order rate } \\
\text { constant, } k^{\prime}\end{array}$ & $\begin{array}{c}\text { Half-lives, } \\
t_{1 / 2}, \mathrm{~h}\end{array}$ & $R^{2}$ \\
\hline 10 & $\begin{array}{c}0.178 \\
( \pm 0.003)\end{array}$ & 0.374 & 1.82 & 0.9355 \\
\hline 50 & $\begin{array}{c}0.195 \\
( \pm 0.003)\end{array}$ & 0.358 & 1.94 & 0.9287 \\
\hline 100 & $\begin{array}{c}0.221 \\
( \pm 0.003)\end{array}$ & 0.347 & 2.00 & 0.9219 \\
\hline
\end{tabular}

The obtained results indicate an increase of TCC concentration by increasing the HA concentration up to approximately $90 \%$ of the initial TCC added one, this being correlated with the variation of the octanol-water partition coefficient Kow which reflects the distribution ratio of their concentrations between octanol and water, estimating the hydrophobicity of an organic substance. More hydrophobic the compound, it will strongly interact with the lipophilic part of the humic acid, by forming new hydrophilic-hydrophobic mixed structures. These new mixed aggregates will influence the solubility of the hydrophobic compound in water, which will increase by increasing humic acid concentration. In these experiments the concentration of TCC increased from $0.175 \mathrm{mg} / \mathrm{L}$ to $0.210 \mathrm{mg} / \mathrm{L}$ in solutions with concentrations of humic acid ranging from 5 to $125 \mathrm{mg} / \mathrm{L}$.

\subsection{Effect of natural water composition on TCC concentration}

The study of the effect of the composition of natural waters on the TCC concentration was carried out in five natural water samples: mineral water $(M)$; surface water $(F)$, surface water (B), surface water (A) and drinking water (D). A set of triplicates was performed at $25^{\circ} \mathrm{C}$ in a shaking incubator $(120 \mathrm{rpm})$. The obtained results are presented in Table 7 and Figure 2.

It was observed that the TCC solubility is less influenced by the increase of the monovalent cation
Table 7. Effect of the chemical matrix of natural waters on TCC concentration

\begin{tabular}{|l|c|c|c|c|}
\hline \multicolumn{1}{|c|}{$\begin{array}{c}\text { Naturals } \\
\text { waters }\end{array}$} & $\begin{array}{c}\text { TCC } \\
\text { concen- } \\
\text { tration, } \\
\mathrm{mg} / \mathrm{L}\end{array}$ & $\begin{array}{c}\text { Pseudo first- } \\
\text { order rate } \\
\text { constant, } k^{\prime}\end{array}$ & $\begin{array}{c}\text { Half-lives, } \\
t_{1 / 2}, \mathrm{~h}\end{array}$ & $R^{2}$ \\
\hline $\begin{array}{l}\text { Mineral } \\
\text { water (M) }\end{array}$ & $\begin{array}{c}0.0650 \\
( \pm 0.0020)\end{array}$ & 0.493 & 1.41 & 0.9615 \\
\hline $\begin{array}{l}\text { Surface } \\
\text { water (F) }\end{array}$ & $\begin{array}{c}0.0560 \\
( \pm 0.0012)\end{array}$ & 0.513 & 1.35 & 0.9523 \\
\hline $\begin{array}{l}\text { Surface } \\
\text { water (B) }\end{array}$ & $\begin{array}{c}0.0680 \\
( \pm 0.0025)\end{array}$ & 0.398 & 1.74 & 0.9027 \\
\hline $\begin{array}{l}\text { Surface } \\
\text { water (A) }\end{array}$ & $\begin{array}{c}0.0820 \\
( \pm 0.0010)\end{array}$ & 0.231 & 3.00 & 0.9454 \\
\hline $\begin{array}{l}\text { Drinking } \\
\text { water (D) }\end{array}$ & $\begin{array}{c}0.0930 \\
( \pm 0.0025)\end{array}$ & 0.278 & 2.49 & 0.9702 \\
\hline
\end{tabular}

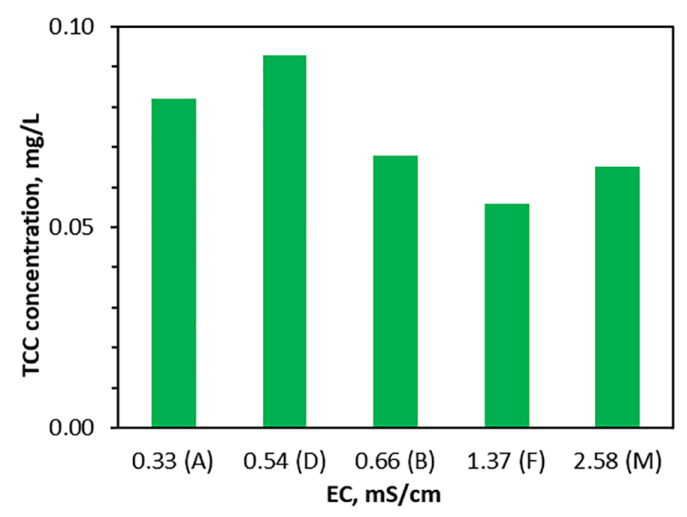

Figure 2. Variation of TCC concentration with the electrical conductivity of natural waters

concentration. In $\mathrm{NaCl}$ solution of different concentrations, it will not decrease till $0.1 \mathrm{mg} / \mathrm{L} \mathrm{NaCl}$, but it will be influenced at higher concentrations.

In the presence of divalent cations, the decrease of the solubility is higher at small concentrations of the salts (178.7, 32.5 and $26.2 \mathrm{mg} / \mathrm{L}$ ).

In aqueous solutions of humic acids and inorganic salts, the solubility of TCC varies in a more complex way, it might increase due to the composition of humic acids and to the interactions between the TCC molecules and the HA ones, but it remains inhibited by the presence of mono and divalent cations from inorganic salts. In natural waters, in more complex matrices TCC solubility varies in correlation with the chemical composition of the matrix and the environmental conditions the process takes place.

\section{Conclusions}

In this study, the effects of temperature, $\mathrm{pH}$, ionic strength and organic matter over the solubility of triclocarban in synthetic aqueous solutions were evaluated, as well as in natural waters, whose chemical compositions were characterized. 
From the obtained data it is observed that the TCC concentration was influenced by: temperature seasonal variation, between 5 and $50^{\circ} \mathrm{C}$; ionic strength variation, a stronger decrease being noticed by increasing the concentration of divalent cations in comparison with the monovalent one in the aqueous matrix; variation of the concentration of the organic matter, the TCC concentration increasing by increasing humic acid concentration till a certain value of $125 \mathrm{mg} / \mathrm{L}$. The variation of the $\mathrm{pH}$ did not show a major influence on TCC concentration in aqueous synthetic solutions. In natural waters the variation of TCC concentration is influenced by the chemical composition of the natural matrix and it decreases by increasing the ionic strength of the aqueous matrix.

This study provides preliminary information about the behaviour of TCC in natural waters depending on their chemical composition. The results could be important for future research in sorption studies in order to remove TCC from natural waters.

\section{References}

Aris, A. Z., Mohd Hir, Z. A., \& Razak, M. R. (2020). Metal-organic frameworks (MOFs) for the adsorptive removal of selected endocrine disrupting compounds (EDCs) from aqueous solution: A review. Applied Materials Today, 21, 100796. https://doi.org/10.1016/j.apmt.2020.100796

Borrirukwisitsak, S., Keenan, H. E., \& Gauchotte-Lindsay, C. (2012). Effects of salinity, $\mathrm{pH}$ and temperature on the octanol-water partition coefficient of bisphenol A. International Journal of Environmental Science and Development, 3(5), 460-464. https://doi.org/10.7763/IJESD.2012.V3.267

Cantwell, M. G., Wilson, B. A., Zhu, J., Wallace, G. T., King, J. W., Olsen, C. R., Burgess, R. M., \& Smith, J. P. (2010). Temporal trends of triclosan contamination in dated sediment cores from four urbanized estuaries: evidence of preservation and accumulation. Chemosphere, 78(4), 347-352.

https://doi.org/10.1016/j.chemosphere.2009.11.021

Commission Directive. (1992). Directive 92/69/EEC of 31 July 1992, A.6 Water solubility. https://eur-lex.europa.eu/legalcontent/EN/TXT/?uri=CELEX:31992L0069

Council Directive. (1976). Council Directive of 27 July 1976 on the approximation of the laws of the Member States relating to cosmetic products (76/768 / EEC, anexa VI, part 1, no. 23). https://eur-lex.europa.eu/LexUriServ/LexUriServ. do?uri=CONSLEG:1976L0768:20100301:en:PDF

Delgado, D. R., Holguin, A. R., \& Martínez, F. (2012). Solution thermodynamics of Triclosan and Triclocarban in some volatile organic solvents. Vitae, 19, 79-92.

https://www.researchgate.net/publication/235577701

Delgado, D. R., Mogollon-Waltero, E. M., Ortiz, C. P., Peña, M. Á., Almanza, O. A., Martínez, F., \& Jouyban, A. (2018). Enthalpy-entropy compensation analysis of the triclocarban dissolution process in some $\{1,4$-dioxane $(1)+$ water $(2)\}$ mixtures. Journal of Molecular Liquids, 271, 522-529. https://doi.org/10.1016/j.molliq.2018.09.026

Diana, M. A., Alejandro, S., \& Fleming, M. (2009). Solution thermodynamics of triclocarban in organic solvents of different hydrogen bonding capability. Journal of Solution Chemistry, 38, 1493-1503. https://doi.org/10.1007/s10953-009-9464-6

Ding, S. L., Wang, X. K., Jiang, W. Q., Zhao, R. S., Shen, T. T., Wang, C., \& Wang, X. (2015). Influence of $\mathrm{pH}$, inorganic anions and dissolved organic matter on the photolysis of antimicrobial triclocarban in aqueous systems under simulated sunlight irradiation. Environmental Science and Pollution Research, 22, 5204-5211.

https://doi.org/10.1007/s11356-014-3686-x

European Commission. (2005). Scientific Committee on Consumer Products SCCP/0851/04, 2005. Opinion on Triclocarban for other uses than as a preservative COLIPA no. P29. https://ec.europa.eu/health/ph_risk/committees/04_sccp/ docs/sccp_o_016.pdf

Halden, R. U., \& Paull, D. H. (2004). Analysis of triclocarban in aquatic samples by liquid chromatography electrospray ionization mass spectrometry. Environmental Science \& Technology, 38(18), 4849-4855. https://doi.org/10.1021/es049524f

Halden, R. U., \& Paull, D. H. (2005). Co-occurrence of triclocarban and triclosan in U.S. water resources. Environmental Science \& Technology, 39(6), 1420-1426.

https://doi.org/10.1021/es049071e

Hynther, A., Bromba, C. M., Wulff, J. E., \& Helbing, C. C. (2011). Effects of triclocarban, triclosan and methyl triclosan on thyroid hormone action and stress in frog and mammalian culture systems. Environmental Science \& Technology, 45(12), 5395-5402. https://doi.org/10.1021/es 1041942

INERIS. (2016). Données technico-économiques sur les substances chimiques en France: Triclocarban (DRC-16-158744-08924A). Portail Substances Chimiques.

http://www.ineris.fr/substances/fr/

Ion, I., Ivan, G. R., Senin, R. M., Doncea, S. M., Capra, L., Modrogan, C., Oprea, O., Stinga, G., Orbulet, O., \& Ion, A. C. (2019a). Adsorption of triclocarban (TCC) onto fullerene C60 in simulated environmental aqueous conditions. Separation Science and Technology, 54(17), 2759-2772. https://doi.org/10.1080/01496395.2019.1577450

Ion, I., Senin, R. M., Ivan, G. R., Doncea, S. M., Capra, L., Henning, M. P, \& Ion, A. C. (2019b). Adsorption of triclocarban on pristine and irradiated MWCNTs in aqueous solutions. Revista de Chimie (Bucharest), 70(8), 2835-2842. https://doi.org/10.37358/RC.19.8.7438

Junhyuk, L., Sunghyun, J., Hwayong, K., Hye, K. C., \& Moon, S. S. (2013). Solubility of triclocarban in pure alkanols at different temperatures. Korean Journal of Chemical Engineering, 30(1), 181-186. https://doi.org/10.1007/s11814-012-0099-8

Kennedy, R. C., Fling, R. R., Terry, P. D., Menn, F. M., Chen, J., \& Borman, C. J. (2015). Extraction of 3,4,4'-Trichlorocarbanilide from rat fecal samples for determination by high pressure liquid chromatography-tandem mass spectrometry. International Journal of Environmental Research and Public Health, 12(7), 8125-8132. https://doi.org/10.3390/ijerph120708125

Lehutso, R. F., Daso, A. P., \& Okonkwo, J. O. (2017). Occurrence and environmental levels of triclosan and triclocarban in selected wastewater treatment plants in Gauteng Province, South Africa. Emerging Contaminants, 3(3), 107-114. https://doi.org/10.1016/j.emcon.2017.07.001

Loftin, K. A., Adams, C. D., Meyer, M. T., \& Surampalli, R. (2008). Effects of ionic strength, temperature, and $\mathrm{pH}$ on degradation of selected antibiotics. Journal of Environmental Quality, 37(2), 378-386. https://doi.org/10.2134/jeq2007.0230

Lv, M., Sun, Q., Xu, H., Lin, L., Chen, M., \& Yu, C. P. (2014). Occurrence and fate of triclosan and triclocarban in a subtropical river and its estuary. Marine Pollution Bulletin, 88(1-2), 383-388. https://doi.org/10.1016/j.marpolbul.2014.07.065

Miller, T. R., Heidler, J., Chillrud, S. N., DeLaquil, A., Ritchie, J. C., Mihalic, J. N., Bopp, R., \& Halden, R. U. (2008). Fate of triclosan and evidence for reductive dechlorination of 
triclocarban in estuarine sediments. Environmental Science \& Technology, 42(12), 4570-4576.

https://doi.org/10.1021/es702882g

Mora, C. P., \& Martínez, F. (2007). Thermodynamic study of partitioning and solvation of (+)-naproxen in some organic solvent/buffer and liposome systems. Journal of Chemical \& Engineering Data, 52(5), 1933-1940.

https://doi.org/10.1021/je700241c

Roman, D., Barnett, E., \& Balske, R. (1957). Cutaneous antiseptic activity of 3, 4, 4'-trichlorocarbanilide. Proceedings of the Scientific Section of the Toilet Goods Association, 28, 12-13.

Sangster, J. (1997). Octanol-water partition coefficients: Fundamentals and physical chemistry (1 ed.). John Wiley \& Sons. https://www.wiley.com/en-us/Octanol+Water+Partition+C oefficients $\% 3 \mathrm{~A}+$ Fundamentals+and+Physical+Chemistry -p-9780471973973

Sapkota, A., Heidler, J., \& Halden, R. (2007). Detection of triclocarban and two co-contaminating chlorocarbanilides in US aquatic environments using isotope dilution liquid chromatography tandem mass spectrometry. Environmental Research, 103(1), 21-29. https://doi.org/10.1016/j.envres.2006.03.006

Schebb, N. H., Inceoglu, B., Ahn, K. C., Morisseau, C., Gee, S. J., \& Hammock, B. D. (2011). Investigation of human exposure to triclocarban after showering and preliminary evaluation of its biological effects. Environmental Science \& Technology, 45(7), 3109-3115. https://doi.org/10.1021/es103650m

Snyder, E. H., \& O’Connor, G. A. (2013). Risk assessment of land-applied biosolids-borne triclocarban (TCC). Science of The Total Environment, 442, 437-444. https://doi.org/10.1016/j.scitotenv.2012.10.007

Snyder, E. H., O’Connor, G. A., \& McAvoy, D. C. (2010). Measured physico-chemical characteristics and biosolids-borne concentrations of the antimicrobial Triclocarban (TCC). Science of the Total Environment, 408(13), 2667-2673. https://doi.org/10.1016/j.scitotenv.2010.03.001

TCC Consortium. (2002). High production volume (HPV) chemical challenge program data availability and screening level assessment for triclocarban, CAS\#: 101-20-2. 201-14186A. Prepared for the HPV Challenge Program by: The TCC Consortium December 27, 2002.

https://www.aciscience.org/docs/Triclocarban_HPV_Test_ Plan.pdf

Venkatesan, A. K., Pycke, B. F., Barber, L. B., Lee, K. E., \& Halden, R. U. (2012). Occurrence of triclosan, triclocarban, and its lesser chlorinated congeners in Minnesota freshwater sediments collected near wastewater treatment plants. Journal of Hazardous Materials, 229-230, 29-35.

https://doi.org/10.1016/j.jhazmat.2012.05.049

Vimalkumar, K., Arun, E., Krishna-Kumar, S., Poopal, R. K., Nikhil, N. P., Subramanian, A., \& Babu-Rajendran, R. (2018). Occurrence of triclocarban and benzotriazole ultraviolet stabilizers in water, sediment, and fish from Indian rivers. Science of the Total Environment, 625, 1351-1360. https://doi.org/10.1016/j.scitotenv.2018.01.042

Vimalkumar, K., Seethappan, S., \& Pugazhendhi, A. (2019). Fate of Triclocarban (TCC) in aquatic and terrestrial systems and human exposure. Chemosphere, 230, 201-209. https://doi.org/10.1016/j.chemosphere.2019.04.145

Wanga, D., Taoa, L., Yanga, J., Xuc, Z., Yanga, Q., Zhanga, Y., Liua, X., Liua, Q., \& Huang, J. (2020). Understanding the interaction between triclocarban and denitrifiers. Journal of Hazardous Materials, 401, 123343. https://doi.org/10.1016/j.jhazmat.2020.123343

Ying, G., Yu, X., \& Kookana, R. (2007). Biological degradation of triclocarban and triclosan in a soil under aerobic and anaerobic conditions and comparison with environmental fate modeling. Environmental Pollution, 150(3), 300-305. https://doi.org/10.1016/j.envpol.2007.02.013

Zhao, J. L., Ying, G. G., Liu, Y. S., Chen, F., Yang, J. F., \& Wang, L. (2013). Occurrence and risks of triclosan and triclocarban in the Pearl River system, South China: From source to the receiving environment. Journal of Hazardous Materials, 179(1-3), 215-222. https://doi.org/10.1016/j.jhazmat.2010.02.082 